\title{
Transport properties of self compacting concrete with limestone filler or fly ash
}

\author{
V. Boel $\cdot$ K. Audenaert $\cdot$ G. De Schutter $\cdot$ \\ G. Heirman · L. Vandewalle $\cdot$ B. Desmet . \\ J. Vantomme
}

Received: 30 January 2006/ Accepted: 18 April 2006/Published online: 13 July 2006

(C) RILEM 2006

\begin{abstract}
The durability of a cementitious material is greatly influenced by the permeability of the material for potentially aggressive substances. As the pore structure of self compacting concrete (SCC) might be different in comparison with traditional concrete (TC), some changes in durability behaviour may occur. At this moment however, it is unclear how significant these differences will be with regard to the concrete practice. In this paper, the gas and water transport in SCC with limestone filler or fly ash is investigated experimentally. Nine different concrete compositions are considered: one TC and eight SCC mixtures. Some important parameters like the water/cement $(\mathrm{W} / \mathrm{C})$ and cement/powder ratio (C/P), type of filler (limestone filler and fly ash), type of aggregate and type of cement are considered. The results of the gas and water transport are discussed and linked to experimental data
\end{abstract}

V. Boel $(\bowtie) \cdot$ K. Audenaert · G. De Schutter

Magnel Laboratory for Concrete Research, Department of Structural Engineering, Ghent

University, Ghent, Belgium

e-mail: veerle.boel@UGent.be

G. Heirman · L. Vandewalle

Reyntjens Laboratory, Catholic University of Leuven, Leuven, Belgium

B. Desmet · J. Vantomme

Royal Military Academy Brussels, Brussels, Belgium concerning pore volume. Lower transport properties can be obtained by using fly ash instead of limestone as filler material, by lowering the $\mathrm{W} / \mathrm{C}$ ratio, decreasing the $\mathrm{C} / \mathrm{P}$ ratio at a constant $\mathrm{W} / \mathrm{C}$ ratio or using blast furnace slag cement instead of portland cement. The effect of changing from gravel to crushed limestone is small. SCC is differing strongly of $\mathrm{TC}$ with respect to the apparent gas permeability. This difference is probably due to the differences in pore volume, as seen from MIP results.

Résumé La durabilité d'un matériau cimentaire dépend largement de sa résistance à l'intrusion d'espèces potentiellement agressives. Dû au changement de la composition du béton autoplaçant (SCC) comparé à celle du béton traditionnel (TC), le système poreux et par conséquent la durabilité pourront être differents face au béton traditionnel. Au moment il n'est pas sûre comment cela va influencer l'emploi du béton à la pratique. Dans cet article les résultats obtenus expérimentalement concernant le transport de gaz et d'eau dans le béton auto-plaçant au filler sont analysés. Neuf gâchées de béton ont été préparées, représentant un béton traditionnel et huit bétons auto-plaçants. Les essais ont été realisés afin d'étudier l'influence de quelques paramètres : le rapport eau/ciment $(W / C)$, le rapport ciment/poudre $(C / P)$, le type de filler (filler calcaire où cendres volantes), le type d'agrégats et le type de ciment. Les résultats concernant le 
transport de gaz et d'eau ont été liés aux résultats expérimentaux de la porosimétrie au mercure. Il est possible de réduire le transport dans le béton en remplaçant le filler calcaire par des cendres volantes, en réduisant le rapport $W / C$, en augmentant le rapport $C / P$ où en utilisant un ciment laitier de haut-fourneau au lieu du ciment Portand. Peu de différence peut être noté concernant la variation $d u$ type d'agregats. Une différence significative néanmoins est déterminée pour la permeabilité apparente de gaz entre le béton auto-plaçant et traditionnel. La différence pourrait être expliquée par la différence en volume des pores des bétons.

Keywords Durability - Gas transport - Liquid transport $\cdot$ Self compacting concrete

\section{Introduction}

Self compacting concrete (SCC) was developed in Japan in the 1980s. The aim was to develop concrete that could be placed without vibration. In this way, some health risks as well as environmental problems could be avoided ("white finger syndrome", noise, vibrations, ...). Also durability problems related with badly vibrated concrete structures could be reduced. Although SCC is a very promising cementitious material, the actual application of SCC might be somewhat riskful due to a lack of fundamental knowledge concerning its durability. Besides the workability and the self-compactability, in the beginning of this project only few fundamental data had been published yet concerning e.g., hydration, permeability and durability. This is illustrated by the proceedings of some important international conferences dealing with SCC [1-6]. The existing recommendations for SCC mainly deal with workability, and hardly treat the behaviour during hardening nor the durability [7-9]. In addition to the available information concerning permeability and durability [10-12], more fundamental knowledge about permeability and durability is needed in order to provide more accurate specifications for the application of SCC.

The permeability for potentially aggressive media of a cementitious material is greatly influenced by the pore structure of the material, as there is an important interaction between 'pore structure', 'transport mechanism' and 'durability'. Furthermore, the ongoing degradation process might have an influence on the pore structure of the material. As the pore structure might be different for SCC in comparison with traditional concrete (TC), due to the difference in composition, some changes in durability behaviour might occur. At this moment, however, it is unclear how significant these differences will be with regard to the concrete practice. A fundamental bottle neck in this discussion is the lack of fundamental insight in the transport behaviour of potentially aggressive media in SCC. As the conception of SCC is totally different from TC, traditional models cannot be extrapolated as such without any verification. This is already illustrated by the experimental and theoretical investigation of hydration, carried out at the Magnel Laboratory for Concrete Research. According to [13] the hydration models valid for TC have to be modified when applied to SCC. In this paper the transport behaviour of nine mixtures will be discussed and analysed.

\section{Design and methodology}

The degradation mechanisms are greatly influenced by the permeability of the material for potentially aggressive media. The penetration of liquids and gasses in SCC was studied firstly by means of basic tests. For liquids, standard tests available at the participating research institutes are applied, including permeability tests and capillary absorption tests. For the study of the penetration of gasses, a gas permeability-measuring instrument according to the RILEM-Cembureau method was used. Also the water vapour diffusion has been investigated. The basic tests should lead to the determination of the fundamental parameters governing the penetration behaviour of liquids and gasses in SCC. The correlation with pore structure will be investigated, and it will be verified whether traditional pore models can be applied to the new cementitious material.

In this article the results on the transport properties, i.e., water permeability, capillary suction, water vapour diffusion and gas permeability, will 
be given and discussed. Some experimental data concerning pore volume is also presented.

\section{Mixture proportions}

During the experimental programme eight mixtures of SCC and one mixture of TC are tested. In the SCC mixtures, a constant amount of fine particles (cement and filler) is considered: $600 \mathrm{~kg} / \mathrm{m}^{3}$. The amount of superplasticizer (polycarboxylic ether) was determined in order to obtain a suitable flowability without segregation. In Table 1 the mixture proportions are given together with the slump flow and the compressive strength at 28 days measured on cubes $150 \times 150 \times 150 \mathrm{~mm}^{3}$. Also the values for the $\mathrm{V}$-funnel, air content and the U-box requiring self-levelling were measured. Besides comparing TC to SCC, the influence of the following parameters is studied: type of cement (portland cement CEM I 42.5 R and blast furnace slag cement CEM III/A 42.5 LA), cement/powder ratio $(\mathrm{C} / \mathrm{P})$, type of filler (limestone filler and fly ash), water/cement ratio (W/C) and type of aggregate (gravel 4/14 and crushed limestone 4/14).

\section{Characterisation of the materials}

\subsection{Aggregates}

River sand $0 / 5$ is used as a fine aggregate. For the coarse aggregate either river gravel $4 / 14$ or crushed limestone 4/14 is used. The crushed limestone 4/14 has been composed of the fractions $2 / 7$ and $7 / 14$ in order to get an almost similar grading curve as for gravel 4/14. The grading curves of the aggregates are presented in Fig. 1.

\subsection{Filler}

The grading curves of the limestone filler and the fly ash used are presented in Fig. 2.

\subsection{Cement}

Portland cement CEM I $42.5 \mathrm{R}$ and blast furnace slag cement CEM III/A 42.5 LA are applied. In Fig. 3 the grading curves of both cement types are given. The grading curves are determined by means of laser diffraction. The Blaine fineness of CEM I $42.5 \mathrm{R}$ and CEM III/ A $42.5 \mathrm{LA}$ is respectively, $351 \mathrm{~m}^{2} / \mathrm{kg}$ and $432 \mathrm{~m}^{2} / \mathrm{kg}$.

\subsection{Superplasticizer}

In this research project a superplasticizer of the third generation is used, namely Glenium 51 con. $35 \%$ which is a polycarboxylic ether.

Table 1 Mixture design

\begin{tabular}{|c|c|c|c|c|c|c|c|c|c|}
\hline & TC1 & SCC1 & $\mathrm{SCC} 2$ & SCC3 & SCC4 & SCC5 & SCC6 & SCC7 & SCC8 \\
\hline CEM I $42.5 \mathrm{R}\left(\mathrm{kg} / \mathrm{m}^{3}\right)$ & 360 & 360 & 360 & 300 & 360 & 360 & 360 & 360 & 360 \\
\hline Limestone filler $\left(\mathrm{kg} / \mathrm{m}^{3}\right)$ & & 240 & $\begin{array}{l}500 \\
240\end{array}$ & 300 & & 240 & 240 & 240 & 240 \\
\hline Fly ash $\left(\mathrm{kg} / \mathrm{m}^{3}\right)$ & & & & & 240 & & & & \\
\hline Water $\left(\mathrm{kg} / \mathrm{m}^{3}\right)$ & 165 & 165 & 165 & 165 & 165 & 144 & 198 & 216 & 165 \\
\hline Sand $0 / 5\left(\mathrm{~kg} / \mathrm{m}^{3}\right)$ & 640 & 853 & 853 & 853 & 853 & 865 & 835 & 825 & 816 \\
\hline Gravel 4/14 $\left(\mathrm{kg} / \mathrm{m}^{3}\right)$ & 1,225 & 698 & 698 & 698 & 698 & 707 & 683 & 675 & \\
\hline Crushed limestone $\left(\mathrm{kg} / \mathrm{m}^{3}\right)$ & & & & & & & & & 734 \\
\hline Superplasticizer $\left(1 / \mathrm{m}^{3}\right)$ & & 2.75 & 2.50 & 2.40 & 3.00 & 4.00 & 2.00 & 2.00 & 3.60 \\
\hline $\mathrm{W} / \mathrm{C}(-)$ & 0.46 & 0.46 & 0.46 & 0.55 & 0.46 & 0.40 & 0.55 & 0.60 & 0.46 \\
\hline $\mathrm{C} / \mathrm{P}(-)$ & 1 & 0.6 & 0.6 & 0.5 & 0.6 & 0.6 & 0.6 & 0.6 & 0.6 \\
\hline $\mathrm{W} / \mathrm{P}(-)$ & 0.46 & 0.28 & 0.28 & 0.28 & 0.28 & 0.24 & 0.33 & 0.36 & 0.28 \\
\hline Slump flow (mm) & - & 875 & 905 & 785 & 800 & 775 & 920 & 805 & 875 \\
\hline Compressive strength (MPa) & 47.6 & 57.1 & 69.2 & 49.0 & 63.5 & 68.4 & 46.7 & 39.9 & 73.3 \\
\hline
\end{tabular}




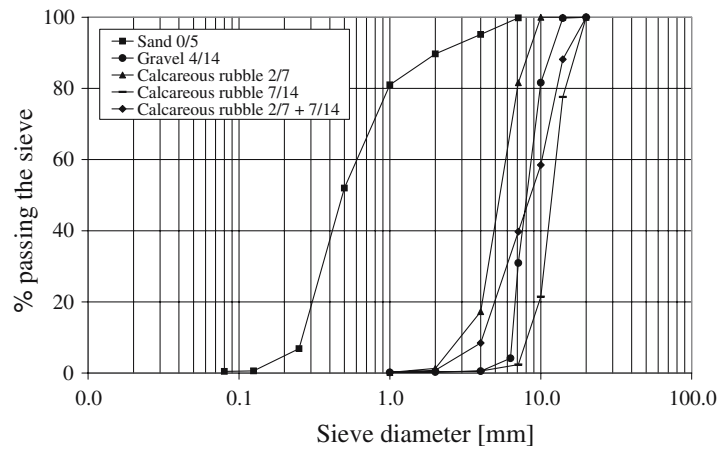

Fig. 1 Grading curves of the aggregates

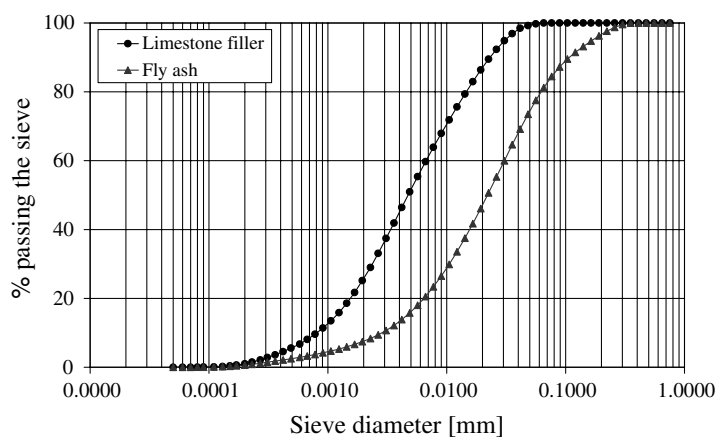

Fig. 2 Grading curves of the fillers

\section{Experimental programme}

\subsection{Study of the liquid transport}

The fundamental parameters describing the liquid transport (capillarity, permeability, ...) are investigated by means of basic experiments.

\subsubsection{Water permeability}

From the mixtures described, cubes $150 \times 150 \times 150 \mathrm{~mm}^{3}$ were manufactured. These concrete cubes were stored in a climate room at $20 \pm 2{ }^{\circ} \mathrm{C}$ and at least $90 \%$ R.H. until the age of 90 days. Then, from the centre of each cube one core diameter $80 \mathrm{~mm}$ and height $25 \mathrm{~mm}$ was taken. Afterwards, these cores were vacuum saturated in water following the Belgian standard NBN B05-202 and put in a testing device, which has been developed at the Magnel Laboratory for Concrete research (Fig. 4).

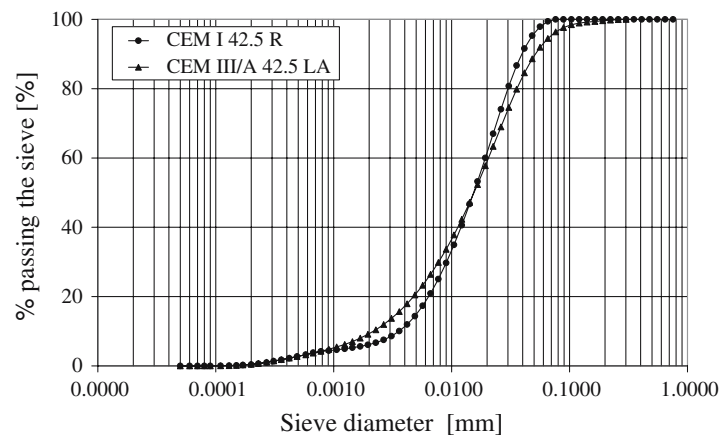

Fig. 3 Grading curve of cement

The upper part of the testing device and the glass tube are filled with water in order to create a pressure head of approximately $500 \mathrm{~mm}$. On this glass tube the height of the water could be determined in function of time. When the steady state flow is reached, the water permeability can be calculated with the following formula (1), based on Darcy's law for laminar flow through porous material:

$K=\frac{A_{\text {tube }}}{A_{\text {specimen }}} \frac{L}{t_{2}-t_{1}} \ln \left(\frac{h_{1}}{h_{2}}\right) \quad[\mathrm{m} / \mathrm{s}]$

with $K$ the coefficient of water permeability [m/s], $A_{\text {tube }}$ and $A_{\text {specimen }}$ the cross sections of the tube and the specimen $\left[\mathrm{m}^{2}\right], L$ the thickness of the specimen [m], $h_{1}$ and $h_{2}$ the pressure head over the specimen [m] at time $t_{1}$ and $t_{2}[\mathrm{~s}]$ respectively. These tests were performed on three specimens for each concrete mixture [14]. In Table 2 the obtained values of $K$ are given.
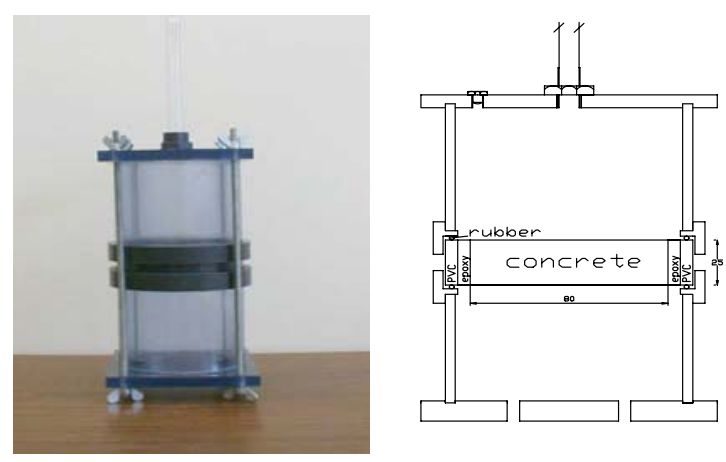

Fig. 4 Testing device for the water permeability 
Table 2 Water permeability $K$ and sorptivity $S$

\begin{tabular}{llllllllll}
\hline & TC1 & SCC1 & SCC2 & SCC3 & SCC4 & SCC5 & SCC6 & SCC7 & SCC8 \\
\hline $\begin{array}{c}\text { Permeability } \\
\quad 10\left(10^{-12} \mathrm{~m} / \mathrm{s}\right)\end{array}$ & 10.0 & 10.5 & 7.5 & 14.8 & 6.3 & 8.1 & 14.1 & 18.3 & 10.4 \\
$\begin{array}{c}\text { Sorptivity } \\
\quad \mathrm{k}\left[\mathrm{kg} /\left(\mathrm{m}^{2} \sqrt{ } \mathrm{h}\right)\right]\end{array}$ & 0.06 & 0.06 & 0.05 & 0.07 & 0.04 & 0.05 & 0.07 & 0.08 & 0.06 \\
\hline
\end{tabular}

\subsubsection{Capillary suction}

From the mixtures described above, cubes $150 \times 150 \times 150 \mathrm{~mm}^{3}$ were made. These concrete cubes were stored in a climate room at $20 \pm 2{ }^{\circ} \mathrm{C}$ and at least $90 \%$ R.H. At the age of 28 days, these concrete cubes were stored for 2 weeks at $35 \pm 5^{\circ} \mathrm{C}$ and $40 \pm 3 \%$ R.H. Afterwards, the capillary suction test was performed in an environment at $20 \pm 3^{\circ} \mathrm{C}$ and $60 \pm 3 \%$ R.H. following the Belgian standard NBN B15-217. The cubes were placed on stable supports in water, so that the water level is $5 \pm 1 \mathrm{~mm}$ above the lower face of the specimen. After 3, 6, 24, 72 and $168 \mathrm{~h}$ the mass of the specimens is determined. From these results the sorptivity $S$ can be calculated (2).

$i=S t^{1 / 2} \quad\left[\mathrm{~kg} / \mathrm{m}^{2}\right]$

With $t$ the time, $i$ the increase in mass $\left[\mathrm{kg} / \mathrm{m}^{2}\right]$ and $S$ the sorptivity index $\left[\mathrm{kg} /\left(\mathrm{m}^{2} \sqrt{ } \mathrm{h}\right)\right]$. The results are given in Table 2. As an example some absorption curves of SCC1, SCC3 and TC1 are given in Fig. 5.

\subsection{Study of the transport of gasses}

\subsubsection{Water vapour diffusion}

The method used to determine the water vapour diffusion is based on DIN 52615 'Bestimmung der Wasserdampfdurchlässigkeit von Bau- und Dämmstoffen'. From the mixtures described above one cube $150 \times 150 \times 150 \mathrm{~mm}^{3}$ was made and stored in a climate room at $20 \pm 2^{\circ} \mathrm{C}$ and at least $90 \%$ R.H. At the age of at least 28 days one core with diameter $80 \mathrm{~mm}$ was taken from the center of the cube. From the center of this core four samples with height $20 \mathrm{~mm}$ were taken and further stored at $20 \pm 2{ }^{\circ} \mathrm{C}$ and at least $90 \%$ R.H. until the age of 6 months. At the testing age the samples are put above a reservoir with a hygroscopic solution of $\mathrm{NH}_{4} \mathrm{H}_{2} \mathrm{PO}_{4}$ in water giving a layer of air with a constant R.H. of $93 \%$

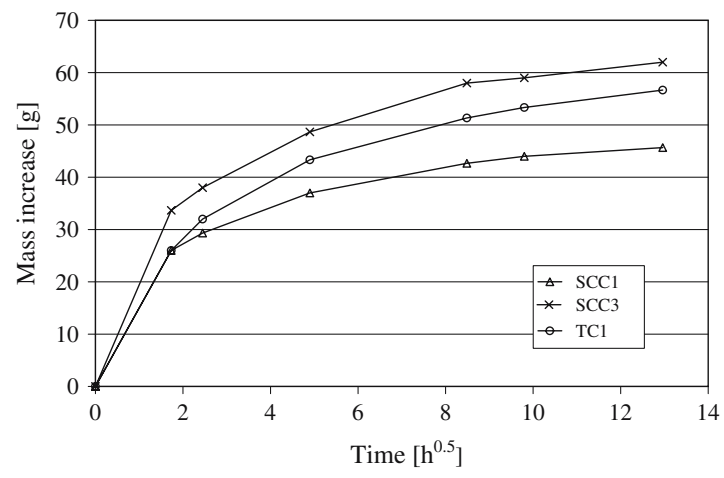

Fig. 5 Absorption curves of SCC1, SCC3 and TC1

between the sample and the water. The sample and the reservoir are then put in a climate room at $20 \pm 3^{\circ} \mathrm{C}$ and $60 \pm 3 \%$. In this way a constant gradient of humidity has been created as such. The mass of the testing device and the sample is measured on a regular base. This makes it possible to calculate the decrease in mass of the water under the sample. The water vapour diffusion coefficients $D$ can be calculated with the following formula (3) and the results are given in Table 3:

$D=J \frac{R T}{M} \frac{L}{p_{1}-p_{2}} \quad\left[\mathrm{~m}^{2} / \mathrm{s}\right]$

with $D$ the water vapour diffusion coefficient $\left[\mathrm{m}^{2} / \mathrm{s}\right], J$ the flux $\left[\mathrm{g} / \mathrm{m}^{2} \mathrm{~s}\right], R$ the universal constant of gas: $8.3145 \mathrm{~J} /(\mathrm{mol} \mathrm{K}), \quad T$ the temperature $[\mathrm{K}], M$ the molecular mass of water $[\mathrm{g} / \mathrm{mol}]$ being $18 \mathrm{~g} / \mathrm{kmol}, L$ the thickness of the specimen [m], $p_{1}$ and $p_{2}$ the vapour pressure at respectively, the side with the higher and the side with the lower relative humidity $\left[\mathrm{N} / \mathrm{m}^{2}\right]$. The flux can be calculated with formula (4):

$J=\frac{I}{A} \quad\left[\mathrm{~g} / \mathrm{m}^{2} \mathrm{~s}\right]$

with $I$ the mass loss of the testing device and the specimen per unit of time $[\mathrm{g} / \mathrm{s}]$ and $A$ the surface 
Table 3 Water vapour diffusion coefficient $D$

\begin{tabular}{|c|c|c|c|c|c|c|c|c|c|}
\hline & TC1 & $\mathrm{SCC} 1$ & $\mathrm{SCC} 2$ & SCC3 & SCC4 & SCC5 & SCC6 & SCC7 & SCC8 \\
\hline $\begin{array}{l}\text { Water vapour diffusion } \\
\text { coefficient }\left(10^{-4} \mathrm{~cm}^{2} / \mathrm{s}\right)\end{array}$ & 22.6 & 19.0 & 19.0 & 22.7 & 5.8 & 15.2 & 30.8 & 58.8 & 13.7 \\
\hline
\end{tabular}

of the specimen $\left[\mathrm{m}^{2}\right]$. The vapour pressure can be calculated as:

$p=\mathrm{RH} p_{\mathrm{s}} \quad\left[\mathrm{N} / \mathrm{m}^{2}\right]$

with $\mathrm{RH}$ the relative humidity $[-]$ and $p_{\mathrm{s}}$ the saturation vapour pressure for a certain temperature $\left[\mathrm{N} / \mathrm{m}^{2}\right]$ (available in tables). In this case the temperature is $20^{\circ} \mathrm{C}$, as such $p_{s}$ equals $2,340 \mathrm{~Pa}$.

\subsubsection{Gas permeability}

The gas permeability coefficient of SCC was studied following a method developed by RILEM TC 116-PCD "Permeability of concrete as a criterion of its durability" [15]. The testing procedure was carried out according to the recommendations of this report.

For each mixture, one slab $400 \times 400 \times 100$ $\mathrm{mm}^{3}$ is made and stored in a climate room at $20 \pm 2{ }^{\circ} \mathrm{C}$ and more than $90 \%$ R.H. At the age of 28 days, three cores of $150 \mathrm{~mm}$ diameter were drilled for each concrete mixture. From the centre of these cores, samples with $50 \mathrm{~mm}$ height were taken. Until the beginning of the test, at the age of 3 months, the samples are stored in a climate room at $20 \pm 2^{\circ} \mathrm{C}$ and more than $90 \%$ R.H. In order to avoid a change of the pore structure during the test, the gas should not react chemically with the concrete. For this reason oxygen is used [16]. Since the saturation degree of the samples is an important issue with regard to the determination of the gas permeability, the test is performed at three different saturation degrees $S$ of which one is the completely dry state of the sample. The drying of the samples is reached according to a fixed procedure, starting from vacuum saturation of the samples after drying at $80^{\circ} \mathrm{C}$ [17]. At this moment the concrete is completely filled with water $(S=100 \%)$ and any flow of gas through the samples is blocked. Further drying of the samples makes it possible to attain two different saturation degrees $S_{1}$ and $S_{2}$. Finally the samples are dried at $105^{\circ} \mathrm{C}$ to reach a saturation degree of $0 \%\left(S_{3}\right)$. The saturation degree $S_{\mathrm{x}}$ can be calculated by means of equation (6):

$S_{\mathrm{x}}=\frac{M_{\mathrm{sx}}-M_{\mathrm{s} 3}}{B-M_{\mathrm{s} 3}} \times 100 \quad[\%]$

with $S_{\mathrm{x}}$ the saturation degree for measurement x (x: 1 till 3) of the gas permeability (volume\%) [\%], $M_{\mathrm{sx}}$ the mass of the sample at that time [g], $M_{\mathrm{s} 3}$ mass of the sample after oven drying at $105^{\circ} \mathrm{C}$, measured at the final stadium of the drying process [g] and $B$ the mass of the vacuum saturated sample measured in the air [g]. The test is performed at three different levels of inlet pressure for oxygen, namely 3, 4 and 5 bar. At each pressure stage the flow rate is allowed to stabilise within $30 \mathrm{~min}$. The flow $Q$ is measured by means of a bubble flow meter. According to [17] the comparison between several mixtures can be based on the gas permeability of completely dry samples at one value of the inlet pressure. In this paper, only the results of the tests with an inlet pressure of 3 and 4 bar and at saturation degree $S_{3}(0 \%)$ will be discussed. The apparent gas permeability kapp can be calculated by means of relationship (7) based on the Hagen-Poiseuille relationship for laminar flow of a compressible
Table 4 Apparent gas permeability coefficient $k_{\text {app }}$

\begin{tabular}{llllllllll}
\hline$P_{1}$ [bar] & \multicolumn{7}{l}{ Apparent gas permeability $k_{\text {app }}\left(10^{-16} \mathrm{~m}^{2}\right)$} \\
\cline { 2 - 9 } & TC1 & SCC1 & SCC2 & SCC3 & SCC4 & SCC5 & SCC6 & SCC7 & SCC8 \\
\hline 3 & 3.018 & 0.544 & 0.506 & 0.652 & 0.428 & 0.271 & 1.382 & 1.853 & 0.451 \\
4 & 2.474 & 0.408 & 0.366 & 0.491 & 0.353 & 0.210 & 1.078 & 1.439 & 0.358 \\
\hline
\end{tabular}


fluid through a porous body with small capillaries under steady-state conditions: [15, 18]

$k_{\text {app }}=\frac{4.04 P_{2} Q L \cdot 10^{-16}}{A\left(P_{1}^{2}-P_{2}^{2}\right)} \quad\left[\mathrm{m}^{2}\right]$

with $Q$ the volume flow rate of the fluid measured during the test with a bubble flow meter $[\mathrm{ml} / \mathrm{s}], L$ the thickness of the specimen in the direction of the flow [m], $A$ the cross-sectional area of the specimen $\left[\mathrm{m}^{2}\right], P_{1}$ and $P_{2}$ the inlet and outlet pressure of oxygen [bar]. This formula is valid for tests performed at $20^{\circ} \mathrm{C}$ for which the viscosity of oxygen is $2.02 \times 10^{-5} \mathrm{Nsm}^{-2}$. The coefficients of apparent gas permeability achieved by performing the test with an inlet pressure of 3 and 4 bar and on completely dry specimens, are given in Table 4.

\subsection{Mercury intrusion porosimetry (MIP)}

In order to have some idea about the pore volume in the different concretes considered in this research, some mercury intrusion porosimetry (MIP) tests have been realised on paste samples, representing the paste fraction in the concretes considered. For more details on MIP, reference is made to literature [19]. Figs. 6-9 show some results of the obtained cumulative pore volume (intrusion and extrusion curves) obtained on the paste samples. Within the legend of these figures, the name of the sample is composed of three characters: "P" to indi-

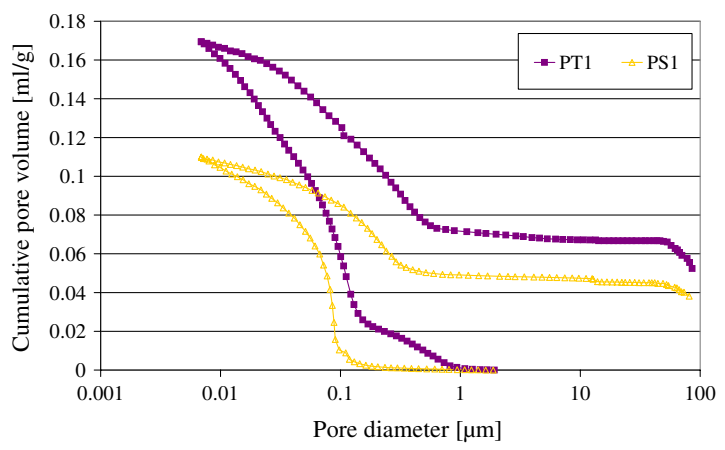

Fig. 6 Cumulative pore volume of a self compacting cement paste PS1 and a traditional cement paste PT1, after 28 days curing

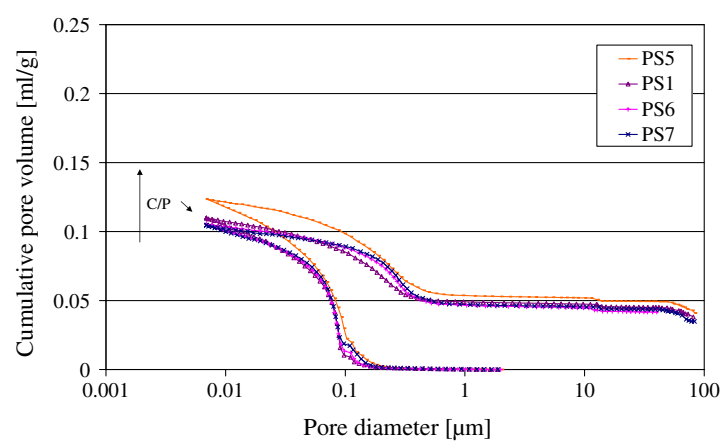

Fig. 7 Cumulative pore volume of self compacting cement pastes with varying $\mathrm{C} / \mathrm{P}$, after 28 days curing

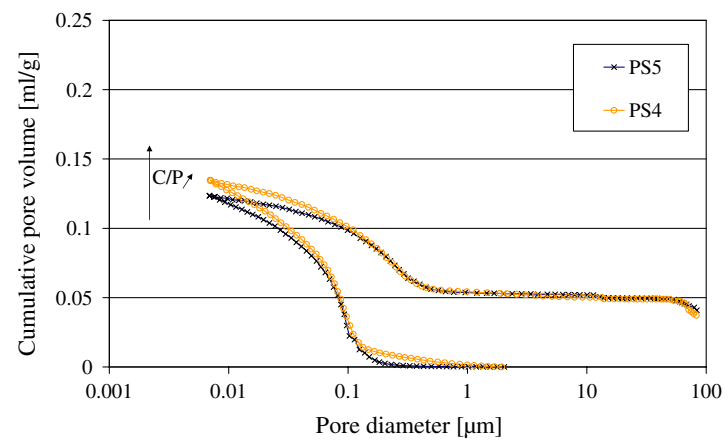

Fig. 8 Cumulative pore volume of self compacting cement pastes with varying $\mathrm{C} / \mathrm{P}$ and constant $\mathrm{W} / \mathrm{C}$, after 28 days curing

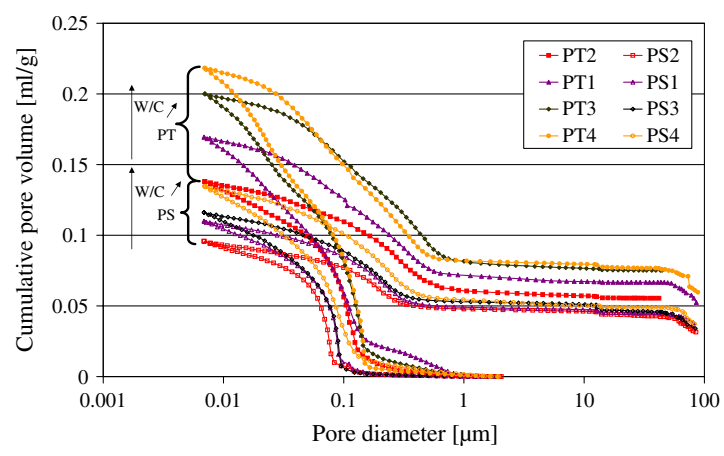

Fig. 9 Cumulative pore volume of self compacting and traditional cement pastes with varying W/C, after 28 days curing

cate that the results are obtained on paste samples, "T" respectively " $S$ " to indicate that the paste is resembling the paste fraction in TC respectively SCC, and a number. The paste compositions tested with MIP are presented in Table 5. 
Paste compositions PT1, PS1, PS5, PS2 and PS4, respectively, correspond with respectively concrete TC1, SCC1, SCC3, SCC5 and SCC6.

\section{Discussion}

From the results on water and gas transport given in Tables 2-4, the following observations can be made:

SCC versus TC (SCC1-TC1): The difference in sorptivity and water permeability is rather small and merely neglectable. The water vapour diffusion coefficient of TC is somewhat higher than of SCC. A big difference however, between SCC and TC can be noticed for the gas permeability. The apparent gas permeability coefficient is, whatever the value of the inlet pressure, six times lower for SCC. The same tendency has been found at other saturation degrees of the samples [20]. This phenomenon has been observed for several mixtures of SCC and TC. Also in [21] this important difference between the gas permeability of traditional and SCC has been found. The answer most probably can be found in the different pore structure of SCC and TC, and the appearance of several flow types like gas slippage, laminar and turbulent flow of oxygen through the pore system. In Fig. 6 the cumulative pore volume of two cement pastes PT1 and PS1 has been plotted. The cumulative porosity of PT1 seems to be significantly higher than that of PS1. Also the critical pore size of PT1 is higher than for PS1. Further investigations are going on.

Type of cement (SCC1-SCC2): Both permeability and sorptivity are decreased by using blast furnace slag cement instead of portland cement.
The higher fineness of the blast furnace slag cement might have induced a finer pore structure. The same conclusion is valid for the gas transport properties.

Cement/powder ratio (SCC1-SCC3-SCC6): In Fig. 7 the cumulative pore volume of some mixtures with increasing $\mathrm{C} / \mathrm{P}$ and constant $\mathrm{W} / \mathrm{P}$ are plotted. When two mixtures with the same $\mathrm{W} /$ $\mathrm{C}(0.55)$ are compared to each other, one can observe in Fig. 8 that increasing the $\mathrm{C} / \mathrm{P}$ from 0.5 (PS5) to 0.6 (PS4), increases the porosity. A higher gas permeability and a higher water vapour diffusion coefficient has been found when SCC3 $(\mathrm{C} / \mathrm{P}=0.5)$ is compared to SCC6 $(\mathrm{C} / \mathrm{P}=0.6)$, both having the same $\mathrm{W} / \mathrm{C}$ of 0.55 .

Type of filler (SCC1-SCC4): When fly ash is used instead of portland cement, a much finer pore structure occurs, causing lower values for the water and gas transport properties. The effect of a finer pore structure is however, less pronounced in the case of the apparent gas permeability.

$\mathrm{W} / \mathrm{C}$ ratio (SCC1-SCC5, SCC6, SCC7): Lowering the $\mathrm{W} / \mathrm{C}$ ratio by decreasing the amount of water and keeping the amount of cement and powder constant, decreases significantly the water and gas transport properties. A higher $\mathrm{W} / \mathrm{C}$ ratio will lead to a more accessible pore structure and higher water and gas transport properties. In Fig. 9 the cumulative pore volume of several traditional and self compacting cement pastes with varying $\mathrm{W} / \mathrm{C}$ are plotted. The porosity increases with increasing W/C. Comparing Figs. 7 and 9 , it can be noticed that the effect of increasing the water content, keeping the amount of powder and cement constant, has a more important impact on the pore structure than changing the cement/powder ratio, keeping the amount of powder and water constant.

Table 5 Mixture proportions $\left(\mathrm{kg} / \mathrm{m}^{3}\right.$ concrete)

\begin{tabular}{lccccccccccc}
\hline & PT1 & PT2 & PT3 & PT4 & PS1 & PS2 & PS3 & PS4 & PS5 & PS6 & PS7 \\
\hline CEM I 42.5 R & 360 & 360 & 360 & 360 & 360 & 360 & 360 & 360 & 300 & 400 & 450 \\
Water & 165 & 144 & 180 & 198 & 165 & 144 & 180 & 198 & 165 & 165 & 165 \\
Limestone filler & - & - & - & - & 240 & 240 & 240 & 240 & 300 & 200 & 150 \\
Glenium 51 $\left(1 / \mathrm{m}^{3}\right)$ & - & - & - & - & 2.8 & 3.2 & 2.6 & 2.3 & 2.3 & 3.1 & 3.4 \\
W/C ratio & 0.46 & 0.40 & 0.50 & 0.55 & 0.46 & 0.40 & 0.50 & 0.55 & 0.55 & 0.41 & 0.37 \\
C/P ratio & 1 & 1 & 1 & 1 & 0.60 & 0.60 & 0.60 & 0.60 & 0.50 & 0.67 & 0.75 \\
W/P ratio & 0.46 & 0.40 & 0.50 & 0.55 & 0.46 & 0.24 & 0.30 & 0.33 & 0.28 & 0.28 & 0.28 \\
\hline
\end{tabular}


Type of aggregate (SCC1-SCC8): When crushed limestone is used instead of gravel, the water permeability and the sorptivity remain more or less the same. The effect of changing the type of coarse aggregate remains in this case rather small. For the water vapour diffusion coefficient and the apparent gas permeability coefficient, lower values are obtained when crushed limestone is used instead of gravel. The adherence of the cement matrix to the coarse aggregates might be somewhat better in the case of crushed limestone. The results on the porosity obtained from MIP on cement pastes are linked with the transport properties of the concrete. A strong correlation has already been found between the capillary porosity and the water permeability [14] and the gas permeability [20] for the described mixtures.

\section{Conclusions}

An experimental programme has been set up in order to examine the transport properties (water permeability, capillary suction, water vapour diffusion and gas permeability) of SCC. Parameters like water content, powder content, type of filler, type of coarse aggregate, type of cement and cement to powder ratio were being investigated. The results on the porosity obtained from MIP on cement pastes are linked with the transport properties of the concrete.

Lower transport properties can be obtained by using fly ash instead of limestone filler, lowering the $\mathrm{W} / \mathrm{C}$ ratio, decreasing the $\mathrm{C} / \mathrm{P}$ ratio at a constant $\mathrm{W} / \mathrm{C}$ or using blast furnace slag cement instead of portland cement. The effect of changing from gravel to crushed limestone is small. SCC is differing strongly from $\mathrm{TC}$ with respect to the apparent gas permeability. This difference is probably due to the differences in pore structure and volume, as seen from MIP results.

Acknowledgments The financial support of the National Fund for Scientific Research-Flanders is greatly acknowledged.

\section{References}

1. Ozawa K, Ouchi M (1999) Proceedings of the International Workshop on Self-compacting Concrete. JSCE Concrete Engineering Series, 30

2. Skarendahl A, Petersson O (1999) Self-Compacting Concrete, Proceedings of the First International RILEM Symposium. RILEM Publications S.A.R.L., Proceedings PRO 7

3. Proceedings of Seminar on Self-Compacting Concrete, European Council for Construction Research, Development and Innovation, Malmö, Copenhagen, 20-21 November 2000

4. Proceedings of the First North American Conference on the Design and Use of Self-Consolidating Concrete, Evanston (USA), 12-13 November 2002

5. Proceedings of Advances in concrete through science and engineering, Evanston, 2004

6. Proceedings of the $3 \mathrm{rd}$ international conference on SCC, 17/8/2003-20/8/2003, Reykjavik, RILEM-2003

7. Billberg P (1999) Self-compacting concrete for civil engineering structures-the Swedish experience. CIB Report 2:99

8. Uomoto T, Ozawa K (1999) Recommendation for selfcompacting concrete. JSCE, Concrete Engineering Series, 31

9. Association Française de Génie Civil (AFGC) 'Bétons auto-plaçants-Recommendations provisoires', Documents scientifiques et techniques, juillet 2000

10. Zhu W, Bartos PJ (2003) Permeation properties of self-compacting concrete. Cement Concrete Res 33:921-926

11. Persson B (2003) Internal frost resistance and salt frost scaling of self-compacting concrete. Cement Concrete Res 33:373-379

12. Persson B (2003) Sulphate resistance of self-compacting concrete. Cement Concrete Res 33:1933-1938

13. Poppe A-M (2004) Influence of fillers on the hydration and properties of self-compacting concrete. Only available in Dutch. Doctoral thesis Ghent University

14. Audenaert K, De Schutter G Water permeability of SCC. In: 'Advances in concrete through science and engineering', Proceedings of International Symposium held during the RILEM Spring Meeting, Evanston, 2004, CD-ROM, paper 39 in session Durability, pp 9

15. RILEM TC 116-PCD: Permeability of Concrete as a Criterion of its Durability-Recommendations, Materials and Structures. 32 (April 1999) 174-179

16. Rilem Report 12, Kropp J and Hilsdorf HK (eds) Performance criteria for concrete durability

17. Carcassès M, Abbas A, Ollivier J-P, Verdier J (2002) An optimised preconditioning procedure for gas permeability measurement. Mater Struct 35:22-27

18. Khan MI (2003 January/February) Permeation of High Performance Concrete M. ASCE. J Mater Civ Eng 84-92 
19. Ye G (2003) Experimental study and numerical simulation of the development of the microstructure and permeability of cementitious materials. Doctoral thesis Delft University

20. Boel V, Audenaert K, De Schutter G Gas permeability of SCC. Proceedings of the Second North American
Conference on the Design and Use of Self-Consolidating $\backslash$ Concrete and the fourth International RILEM Symposium on Self-Compacting Concrete, Chicago, Illinois, USA, October 30-November 2, 2005

21. Assié S (2004) Durabilité des Bétons Autoplaçants. Thèse de doctorat INSA de Toulouse 